\title{
Regulatory Aspects of Mining Waste Management in the Russian Federation
}

\author{
Marina Anatolyevna Nevskaya and Oksana Anatolyevna Marinina
}

National Mineral Resources University (Mining University), 199106, 21 line, 2, Saint-Petersburg, Russia.

DOI: http://dx.doi.org/10.13005/bbra/1942

(Received: 08 August 2015; accepted: 15 September 2015)

\begin{abstract}
The legislation defines the rights and responsibilities of subsoil users and other members of the waste management process, therefore, the state of affairs in this sphere largely depends on its quality. Modern "conflict" of legal acts, which is caused by the absence of state integrated concept of waste management, forms a chain of consequences that lead to their accumulation in the environment. The main problem is still the lack of coordination of environmental and mining legislation, misleading the subsoil users. The possibility to generate incentives for waste reduction, recycling and utilization depends on the state of the institutional environment, which determines the scope of the interaction of economic entities on the basis of the system of legal acts. The aim of the present research is to study the Russian legislation concerning the control of economic relations in the sphere of mining waste handling. In the article the definition of "waste" as the object of management and concepts underlying the regulatory framework of waste management. On the basis of statistical dynamic analysis the relations between the state of the regulatory framework in the waste management and the factors conditioning the negative trends have been identified and summarized. "Conservative" and "liberal" views on elimination of contradictions in the regulatory framework of mining waste handling have been studied. The directions of improvement of the regulatory framework in the sphere of mining waste management upon the "conservative" and "liberal" scenarios have been suggested.
\end{abstract}

Key words: mining waste, waste management concept, regulatory support.

The industrial waste accounts for more than $96 \%$ of all production and consumption waste, calculated by the national statistics. Over $90 \%$ of the total amount of production and consumption waste of all hazard classes, produced in the country per year, are production waste associated with mining; while $57 \%$ of the waste falls on the production of energy resources (Nevskaya, \& Ligotsky, 2013).

By now the dumps of the enterprises engaged in mining in Russia, have accumulated over 16 billion tons of industrial waste in subsoil management.

\footnotetext{
* To whom all correspondence should be addressed.
}

In addition to the deterioration of mining and geological conditions and quality of mineral resources, the factor limiting the active involvement of mining waste into economic circulation, is the lack of incentives to reduction, processing and utilization of mining waste.

In the market economy, the possibility of formation of such incentives largely depends on the state of the institutional environment, which determines the scope of the interaction of economic entities on the basis of the system of legal acts.

According to the data provided by INTOSAI Working Group on Environmental Auditing (WGEA, 2010), performing audits in the sphere of mining operations in different countries, as well as in Russia, there are numerous problems related to non-compliance with laws and regulations 
of tax and environmental legislation, the dumping of toxic waste, violations of environmental standards, mining waste and use of waste dumps.

Considering the problem of mining waste handling, particularly regarding the managerial positions, we identify regulatory support, not only as an instrument of the state control in this sphere, but also as a basis for the formation of the environment, promoting or restricting the economic turnover of mining waste, promoting or hindering the reduction of its accumulation in the environment.

The authors have set the goal not only to assess compliance and quality control of the Russian legislation regulating the activities related to mining waste, concerning the compliance of this legislation with international standards, but also to study such parts of the legislation that hinder the formalization of economic relations in the sphere of mining waste handling.

\section{Review of literature}

Taking into account the vastness of scientific publications devoted to technological and environmental aspects of the problem of waste handling, in particular mining waste handling, in this review we focused on two important, in our view, questions concerning the research topic: the definition of waste as the object of management and concept, reflected in the regulatory support of waste management.

The definition of "waste" is an important component of legal communication, as well as the condition for the effective waste management (Pongrácz, 2002).

In the Russian Federation, the content of the concept "waste" has been disclosed more fully in regulatory documents of the civil branch of the law. The Federal Law of the Russian Federation "On Production and Consumption Waste" "production and consumption waste (hereinafter - the waste) means the substances or objects which are formed during the manufacturing process, performance of works, service rendering or in the process of consumption, which should be removed, are meant to be removed or subject to removal" ("On Production and Consumption Waste” No. 89-FZ, 1998).

The National standard of the Russian Federation defines the "waste" as "remnants of the products or an additional product formed in the process or after completion of certain activities and not used in direct connection with this activities" (the National Standard of the Russian Federation. Resource-saving, 2009).

We agree with the opinion (Pongrácz, 2002) that the waste is more fully characterized by two features - the presence of the owner and the purpose of its use.

This position is reflected in GOST R ISO 14050-2009, Article 3.12 - "Waste are the substances or objects the owner wants to get rid of" that, in particular, corresponds to the definition of "waste" in the EU Directive on Waste (EC Waste Framework Directive, 1991).

At the same time, mining legislation, which regulates the use of mining waste, has no definition of the category "waste" in relation to this area of activity. "The Law on Subsoil" contains the concept of "waste of mining and related processing industries", but does not disclose its contents.

In legal documents the other terms are also used: for example, the terms "technogenic formations" and "technogenic deposits" are included in the Tax Code of the Russian Federation (Article 334, Paragraph 4 of the Tax Code), these terms can also be found in other documents, but they are not defined as juridical definitions.

However, the term "technogenic deposit", which has already become encyclopedic (Troubetskoy, et al., 1989), was introduced into the scientific vocabulary in $70-80$-ies of the twentieth century - the period of formation of the concept of intensive resource-saving in the mineral-resources sector. Currently, the most common definitions of technogenic deposits are as follows: "large-tonnage accumulations of production and mineral processing waste" (Chaynikov, et al., 2000), mineral concentrations (Makarov, 2012), or the secondary mineral resources (Gorlova, 2001). In any case it is proposed to efficiently use the resources of technogenic deposits in the present or the future (with the development of science and technology) (Mormile, et al., 2002).

In addition to "technogenic deposits", the term "technogenic mineral resources" is used in the scientific vocabulary in order to define mineral resources of technogenic origin, which are understood as "a set of technogenic mineral resources contained in the waste of mine-mill and 
metallurgical (chemical) production within one certain region or country as a whole" (Perepelitsyn, et al., 2013),"stocks of technogenic mineral resources” (Troubetzkoy, et al., 1989), (Galperin, 2012), "waste, residues of raw materials, materials, semi-finished products, other goods or products formed during production or consumption that can be used to create different types of use-values “ (Chaynikov, 2000).

Despite the differences in interpretation, the above-mentioned definitions actually identify residues with potential mineral resources.

In the definitions of most researchers there is one dominating view, based on the concept of industrial metabolism (Ayres, \& Simonis, 1994), according to which the waste utilization in production, not waste burial or disposal, should be considered as overriding priority.

The industrial metabolism is a "theoretical forerunner of industrial ecology” (McKinley, \& Avenue, 2008) - the concept that currently defines the philosophy of European environmental legislation. In particular, the EU Directive "On the mining waste management" provides the compliance of basic questions with mining waste management, the principles and priorities identified by the objectives of the policy of the Environmental Protection Community.

In the framework of the concept of industrial ecology the theory of waste management was developed and presented in the thesis of Rongrácz E. "Re-defining the concepts of waste and waste management", the basic idea of which was waste prevention (Rongrácz, Phillips, \& Keiski, 2004). This idea, presented as recommendations to the selection of options for waste management, is reflected in the "waste hierarchy" of the Framework Directive on Waste (2008/98/EC).

Current Russian legislation (basic documents include the laws "On Subsoil" and "On Production and Consumption Waste in the Russian Federation”), regulating mining waste handling ("On Production and Consumption Waste" No. 89-FZ, 1998), does not have a single conceptual framework that would allow to consider the resource and environmental waste components in a consistent manner. Such a situation can be considered as the heritage of the centralized economy, where the production problems of the industrial development were dominated and environmental problems were solved residually.

The most complete extraction of subsoil reserves of basic and minerals, imbedded together with such reserves, as well as associated components, is considered as one of the principles of rational subsoil use (the Federal Law "On Mineral Wealth”, 1992, Article 23.5). The validity of this principle is difficult to refute, if not taking into account that this principle can be applied to extraction and mineral processing waste, as according to the law "On Subsoil" the activity associated with waste utilization (processing) refers to a form of subsoil use. Experience has shown that sometimes the use and disposal of mining waste can cause considerable environmental and social damage (Scannell, 2012). At the same time, complex extraction of useful components does not lead to a decrease in the environmental impact of waste, as the weight of waste remains unchanged. Therefore, the development of the technogenic object does not guarantee the solution of environmental problems (Kiperman, et al., 2013).

From our point of view, the main problem remains not a question of dual regulation of activities related to mining waste handling, but the lack of coordination of environmental and mining legislation, misleading subsoil users.

The relevance of the regulatory aspect of this problem in Russia is enhanced by the following circumstances:

Firstly, in the free market the requirements for the legal system and its ability to provide regulation of economic relations in the management of mining and mineral processing waste are greatly increased.

Secondly, the process of integration of Russia into the global economic system requires a certain unification and standardization of legal documents in the mining waste management, with the strengthening of the environmental component of the Russian mining legislation.

Thirdly, there is an urgent need for clear procedures, rules and requirements, allowing to develop forms of economic cooperation in the waste management, and effectively manage this process.

\section{Methods of the study}

The present study is based on the data of the official Russian statistics for identification 
of trends in formation, utilization and accumulation of mining waste in the mineral extraction. The methods involves the use of methods of statistical dynamic analysis in order to summarize the results obtained, identification of factors-reasons, determining major trends in the sphere of mining waste handling, logical identification of the links between the state of the legal framework in the waste management handling and the factors conditioning the negative trends.

\section{Results of the study}

On the basis of summarizing the information of the state statistics on the volume of industrial production and waste formation in mining, represented by official statistics, the indicators of waste volume in the environment have been calculated (see Table 1).
These results obtained confirm the findings that waste from extractive industries accounts for the bulk of the waste in Russia, more than $90 \%$.

Even if we consider that a part of this waste falls on production and consumption waste, not related to mining (since the data of official statistics do not reflect the waste volume, directly related to the extraction of mineral resources), the scope of their formation is significant and processing volumes do not exceed $50 \%$ of the total weight of waste produced. Thus, more than $50 \%$ of production and consumption waste produced per year, related to mining operations, are accumulated in the environment, at the same time, the great bulk of waste (over $60 \%$ ) falls on the fossil-fuels production. If in 2005, in average

Table 1. Data on the volume of industrial production, waste formation and accumulation

\begin{tabular}{|c|c|c|c|c|c|c|c|c|c|}
\hline Period & 2005 & 2006 & 2007 & 2008 & 2009 & 2010 & 2011 & 2012 & 2013 \\
\hline \multicolumn{10}{|c|}{ Formation of production and consumption waste by economic activity, mln. tons } \\
\hline Total volume & 3035.5 & 3519.4 & 3899.3 & 3876.9 & 3505 & 3734.7 & 4303.3 & 5007.9 & 5152.8 \\
\hline including mining waste & 2506.2 & 2923.5 & 2785.2 & 3402.4 & 3066.5 & 3334.6 & 3818.7 & 4629.3 & 4701.2 \\
\hline including waste from & 1498.6 & 1732.1 & 1636.3 & 2089.9 & 1984.9 & 2204.3 & 2527.8 & 3022.8 & 3010.5 \\
\hline \multicolumn{10}{|c|}{ fossil fuels extraction $\quad$ Waste utilization and disposal by economic activity, mln. tons } \\
\hline Total volume & 1262.8 & 1395.8 & 2257.4 & 1960.7 & 1661.4 & 1738.1 & 1990.7 & 2348.1 & 2043.6 \\
\hline including mining waste & 1070.4 & 1144.5 & 1829.4 & 1723.6 & 1469.4 & 1562.2 & 1800.1 & 2125.9 & 1753.1 \\
\hline including waste from & 833.1 & 918.9 & 1051.1 & 1320.3 & 1132.5 & 1206.2 & 1341.1 & 1589.3 & 1120.2 \\
\hline \multicolumn{10}{|c|}{ The volume of waste accumulation, mln. tons } \\
\hline Total volume & 1772.7 & 2123.6 & 1641.9 & 1916.2 & 1843.6 & 1996.6 & 2312.6 & 2659.8 & 3109.2 \\
\hline including mining waste & 1435.8 & 1779 & 955.8 & 1678.8 & 1597.1 & 1772.4 & 2018.6 & 2503.4 & 2948.1 \\
\hline including waste from & 665.5 & 813.2 & 585.2 & 769.6 & 852.4 & 998.1 & 1186.7 & 1433.5 & 1890.3 \\
\hline \multicolumn{10}{|c|}{ fossil fuels extraction $\quad$ The volume of production of the basic fossil fuels, mln. tons } \\
\hline Coal production, mln. tons & 299 & 310 & 314 & 329 & 301 & 322 & 336 & 357 & 351 \\
\hline Oil and gas condensate, mln. tons & 470 & 481 & 491 & 488 & 494 & 506 & 512 & 519 & 522 \\
\hline $\begin{array}{l}\text { Total volume of fossil fuel } \\
\text { production, } 2 \text { mln. tons }\end{array}$ & 769 & 791 & 805 & 817 & 795 & 828 & 848 & 876 & 873 \\
\hline
\end{tabular}

(coal mining waste is objectively dominated in total waste volume) about 2 tons of recovered waste falls on each ton of extracted fossil fuels, while in 2009 - more than 2.5 tons, and in 2013 - 3.45 tons. Similar rates of waste accumulation were respectively equal to $0.87 ; 1.07$ and 2.17 tons per ton of extracted fossil fuels.

According to the source (The Resolution of the Government of the Russian Federation "On the federal target program "Ecology and Natural Resources of Russia, 2001), by 2001 on the territory of Russia over 80 billion of mining waste, which number is increasing annually by almost 2 billion tons, have been accumulated in the waste dumps and storage; waste burial sites, sludge collectors and tailings ponds cover more than 300 thousand hectares of land.

Over 16 billion of such waste was accumulated during the period of 2005-2013, i.e. in total the volumes of waste accumulation currently exceeded 100 billion tons.

For the analysis of general trends and 
more accurate use of statistical information we used calculated chain indices of formation, utilization and accumulation of mining waste (2005 was adopted as the basis year) (Table 2).

In 2008 and 2009, there were the lowest rate of growth of industrial production, while the index of waste accumulation was as follows: 1.32 in 2008 and 1.11 in 2009. Over the entire analyzed period (except for 2007), the rate of waste accumulation considerably exceeded the indices of industrial production in the mining sector.

To obtain a complete picture of the scope of mining waste handling, the study includes baseline and average indices of growth and growth in the analyzed indicators (Table 3)

In order to obtain a complete review of the situation in mining waste handling reference and annual average indices of growth and an increase in the analyzed indicators were included in the study (Table 3).

The analysis of official statistical information led to the conclusion that, despite the increase in the use and disposal of waste, there has been steady growth in the volume of waste formation and accumulation. Compared with 2005, the growth in waste production exceeded the growth in production by 1.62 times, while waste accumulation exceeded by 1.77 times. The accumulated stocks of waste has doubled over 9 years, more than half of the waste falls on the waste from fossil fuel extraction. In addition, the stocks of generated waste are increasing at a faster pace than the volume of waste recycling and disposal.

Waste stocks, accumulated in the dumps and tailing ponds, at an average thickness of $20 \mathrm{~m}$ cover an area of over $1,300 \mathrm{~km}^{2}$. The annual increase

Table 2. The rate of mining waste formation, utilization (disposal) and accumulation

\begin{tabular}{|c|c|c|c|c|c|c|c|c|c|}
\hline Period & 2005 & 2006 & 2007 & 2008 & 2009 & 2010 & 2011 & 2012 & 2013 \\
\hline \multicolumn{10}{|c|}{ The rate of waste formation } \\
\hline Total volume & 1.15 & 1.16 & 1.11 & 0.99 & 0.9 & 1.07 & 1.15 & 1.16 & 1.03 \\
\hline including mining waste & 1 & 1.17 & 0.95 & 1.22 & 0.9 & 1.09 & 1.15 & 1.21 & 1.02 \\
\hline including waste from & 1 & 1.16 & 0.94 & 1.28 & 0.95 & 1.11 & 1.15 & 1.2 & 1 \\
\hline \multicolumn{10}{|c|}{ The rate of waste utilization and disposal } \\
\hline Total volume & 0.9 & 1.11 & 1.62 & 0.87 & 0.85 & 1.05 & 1.15 & 1.18 & 0.87 \\
\hline including mining waste & 1 & 1.07 & 1.6 & 0.94 & 0.85 & 1.06 & 1.15 & 1.18 & 0.82 \\
\hline including waste from & 1 & 1.1 & 1.14 & 1.26 & 0.86 & 1.07 & 1.11 & 1.19 & 0.7 \\
\hline \multicolumn{10}{|c|}{ The rate of waste accumulation in the natural environment } \\
\hline Total volume & 1.18 & 1.2 & 0.77 & 1.17 & 0.96 & 1.08 & 1.16 & 1.15 & 1.17 \\
\hline including mining waste & 1 & 1.24 & 0.54 & 1.76 & 0.95 & 1.11 & 1.14 & 1.24 & 1.18 \\
\hline including waste from & 1 & 1.22 & 0.72 & 1.32 & 1.11 & 1.17 & 1.19 & 1.21 & 1.32 \\
\hline \multicolumn{10}{|c|}{ Indices of industrial production } \\
\hline Total volume & 105.1 & 106.3 & 106.8 & 100.6 & 90.7 & 104.2 & 108.7 & 102.6 & 100.4 \\
\hline Mining operations, including & 101.4 & 102.8 & 103.3 & 100.4 & 99.4 & 103.6 & 101.9 & 101.1 & 101.1 \\
\hline fossil fuels extraction & 102 & 102.7 & 102.7 & 100.1 & 100.4 & 103.1 & 101,3 & 101.2 & 100.9 \\
\hline
\end{tabular}

in the area of alienated land is not less than 85-90 $\mathrm{km}^{2}$. The negative impact on the environment is manifested in the territory 10 times or more greater than the area occupied by waste (Bokov, 1994).

The identified trends are due to several factors:

The deterioration of mining and geological conditions of mining operations

Mining and geological conditions are determined by the general state of the mineral resource base and the technology of development of indigenous deposits, as well as by:

1) low content of useful components in significant quantities of balance reserves on most minerals;

2) deterioration of the stocks of deposits due to long-term mining of the largest objects with high-quality stocks;

3) exhausted fund of deposits with openaccess reserves, in the result of which it is required 
to extract a larger volume of the rock mass in order to produce the same amount of product. More than $75 \%$ of hydrocarbon deposits, involved in the exploitation, have been mined out by half; the share of hard-recoverable reserves is constantly growing (as for major oil companies, this share ranges from 30 to 65\%) (Krukov, et al., 2011).

The existing technological conditions of mining operations, characterized by inefficient use of mineral raw materials, the use of technologies and systems of deposit development, leading to an increase in the amount of waste of recoverable resources.

\section{The quality of waste as raw materials for industrial processing}

The change in the quantitative and qualitative composition of the waste, resulted from long-term storage, limits its industrial processing. The processes of oxidation, resolution of the waste mineral substance can occur due to the influence of atmospheric precipitation, - therefore occurs the deterioration of its qualities as potential raw material (Seleznyov, 2013).

Weak motivation for the introduction of technologies on reduction of waste formation and recycling

a) lack of economic incentives and commercial interest in the complex processing of extracted mineral resources and extraction of useful components;

b) low cost of land;

c) lack of control over the formation and disposal of mining waste.

The practice of providing primary deposits for their development

One of the drawbacks of the current system of granting rights to use subsoil resources is underestimation of the possibilities of using the waste left from past activities, as there is no mechanism of limitation of mineral extraction in the presence of regional anthropogenic sources of mineral raw materials of this type.

Inconsistence of the systems of accounting for mining waste

Accounting for reserves and mining waste containing in waste of mining and related processing industries, are separate the accounting system, actually isolated from one another:

a) accounting for mining waste on environmental and mining legislation is conducted on different classification criteria. The main parameters that characterize the waste as environmentally hazardous objects, are the type, amount (weight), the content of harmful components, hazard class, places of

Table 3. Indices characterizing the volume of waste production, formation and utilization (disposal) and accumulation for the period of 2005-2013

\begin{tabular}{|l|c|c|c|c|}
\hline \multirow{2}{*}{ Indices } & \multicolumn{2}{|l|}{$\begin{array}{l}\text { Reference indices } \\
\mathbf{( 2 0 1 3} \text { to 2005 })\end{array}$} & \multicolumn{2}{l|}{ Annual average indices, \% } \\
\cline { 2 - 5 } & rate of growth & rate of increase & rate of growth & rate of increase \\
\hline Volume of mining waste production & 116 & 16 & 101.8 & 1.8 \\
\hline $\begin{array}{l}\text { Including waste from fossil fuels } \\
\text { extraction }\end{array}$ & 115 & 15 & 101.7 & 1.7 \\
\hline Volume of mining waste formation & 188 & 88 & 108.2 & 8.2 \\
\hline Including waste from fossil fuels extraction & 201 & 101 & 109.1 & 9.1 \\
\hline Volume of mining waste processing & 164 & 64 & 106.3 & 6.3 \\
\hline Including waste from fossil fuel extraction & 134 & 34 & 103.7 & 3.7 \\
\hline Volume of mining waste accumulation & 205 & 105 & 109.4 & 9.4 \\
\hline Including waste from fossil fuel extraction & 284 & 184 & 113.9 & 13.9 \\
\hline
\end{tabular}


accumulation. Accounting for mining waste is provided by the State Waste Inventory (SWI) on the basis of the above-mentioned features. According to the law "On Subsoil”, mineral resources and useful components containing in the waste, accounting of which is provided by the State Reserves Register, not masses of waste, are the objects of accounting;

b) accounting principles of mining waste management differ from each other: according to the environmental legislation the accounting is held on the basis of lifecycle stages - starting from waste generation to waste utilization or disposal. Mining legislation provides for a different system, based on the accounting of management of reserves of mineral resources contained in the masses of waste by putting them on balance, transferring reserves from the category of balance reserves to the off-balance ones (and vice versa), as well as by writing the reserves off in the form of losses;

c) reclaimed and "preserved" masses of waste are not included in the Waste Register of the State Waste Inventory, and these reserves are placed on the state balancesheet only in cases of commercial interest.

Barriers in attraction of small and medium-sized mining business into the sphere of mining waste handling

a) a high degree of monopolization of the market in the mineral resources sector, while the processing of mining waste is not always the object of the commercial interests of major companies.

b) duration and high costs of the procedure (through an auction) for acquisition of rights to use technogenic mineral objects;

c) lack of financial incentives for supporting utilization of extraction and processing waste (preferential loans and taxation).

Inability of the subsoil user to rightfully dispose of production waste on the right of ownership due to the undetermined legal status of waste

The Law "On Production and Consumption Waste" (Article 1 of the "General Provisions"), relating to the civil branch of the law, qualifies the use of mining waste as the activity related to waste handling ("On Production and Consumption Waste" No. 89-FZ, 1998). The ownership right to the waste, determined in accordance with the civil law, provides a wider range of authorities of their owners.

The Law "On Subsoil", relating to the administrative branch of law, refers the activities related to the use of mining waste, to the form of subsoil use, that automatically confirms the state's ownership right to this waste. The subsoil user has the right to use waste for mining (extraction of useful components), unless otherwise provided by the license for subsoil use, or to use waste for production purposes (for example, for goave stowing), if provided by the technical project. In other words, a subsoil user is a "producer" of waste, who has right to independently use (extract useful components), or store them expecting possible future prospects, but he/she has no right to dispose of them, involving, for example, the companies that use advanced technologies, but do not have a license for subsoil use.

One of the basic positions of the Russian mining legislation is to review the mining waste as a potential source of mineral resources, while environmental legislation consider the waste as a potential source of environmental hazard.

Thus, the "conflict" of legal acts, based on the absence of a coherent state concept of waste management, forms a chain of consequences, ultimately leading to waste accumulation in the environment.

The factors identified in the study have been combined into interconnected groups of factors that, in our opinion, affect the process of waste accumulation in the established order:

a) mining-technological group of factors (for instance, the geological conditions, the composition of minerals, the composition of waste, mining technologies, etc.);

b) economic group of factors (the undeveloped system of incentives and motivations for complex processing of mineral resources, extraction of useful components, waste recycling, the barriers to attraction of small and medium-sized businesses to waste recycling, etc.).

c) organizational and managerial group of factors (procedures and rules for provision of subsoil for use, the accounting system 
of waste, etc.);

d) regulatory group of factors (definitions, rights to waste and their limitations, regulations, standards, etc.) (see Figure 1).

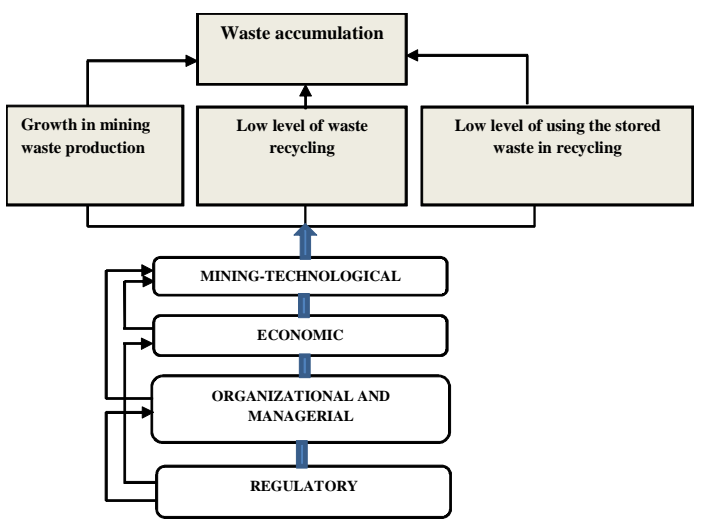

Fig. 1. The plan of the influence of groups of factors on mining waste accumulation

\section{DISCUSSION}

The study revealed two main points of view on the solution of the problem of elimination of contradictions in the regulatory support of mining waste management - "conservative" and "liberal" points of view.

The conservative point of view corresponds to a greater extent to the position of the authorities - the Federal Agency of Subsoil Usage (Nekrasov, 2013), and partly - to the position of large business representatives, forced to incur substantial costs associated with mining waste placement and storage (Popov, 2013). The liberal point of view reflects the views of representatives of small and medium-sized mining business, whose participation in waste recycling is often limited by the duration and high costs of procedures ensuring an access to mining waste (Seleznev, 2013).

The main difference in these points of view includes the classification of types of activities related to mining waste management (refer these activities to a certain type of subsoil use or not), as well as related to the implementation of such proprietary rights in a form of waste disposal.

The analysis of the legislation in waste management in some industrialized countries has shown that the ownership of the waste is assigned to their producer ("abandoned" waste may be an exception) (The Mines and Minerals Act of Canada, 1991).

Solving the problem of categorizing mining waste as waste, the legislation of foreign countries offers a variety of approaches, however, in any case, regulatory support of mining waste management takes an independent place in the legislation.

For example, the law "On Subsoil and Subsoil Use" of Kazakhstan (Law on "On Subsoil and Subsoil Use” of the Republic of Kazakhstan, 2010) defines such a term as "technogenic mineral formations", "technogenic deposits" representing stocks of minerals and intended for perspective recycling. At the same time, it has been determined that the technogenic mineral formations are the property of subsoil users; except for technogenic mineral formations, stored until May 30, 1992 or included in the state fund of mineral resources.

EU Directive "On the management of extractive industry waste" sets the general vector of mining waste management, but for European countries specific legislative measures are largely determined by the value of mineral resources in the national economy, resource saving policy, energy efficiency, environmental restrictions.

Improving the regulatory framework in the sphere of mining waste management upon the "conservative" scenario shall require:

1. To make substantial amendments and additions to the Law "On Subsoil”, as well as to corresponding regulatory legal acts of civil, administrative, environmental legislation, industry regulations (instructions, methods, standards, etc.).

2. To develop own classifier of mining waste and waste from processing industries, with the purpose of waste calculation in the state system. In this regard, changes in the requirements for maintenance of the state balance of stocks may be required.

3. To develop regulations on strict control of mineral production and processing technologies, waste decommissioning and storage for possible future use; to introduce a term "technogenic deposit" to the legal vocabulary.

4. To review the requirements for geological study and geological and economic 
evaluation of technogenic objects due to different nature of the distribution of useful components in technological and indigenous deposits.

5. To develop procedures for alienation of mining waste in the case of violation of the conditions of their formation, storage and recycling.

6. To develop a system of state incentives for the introduction of new technologies for waste recycling.

Referring the management of activities related to waste production and recycling to the sphere of civil law, i.e. the implementation of the "liberal" scenario, should include:

1. Making amendments to regulations (primarily, to the Law "On Subsoil”) in order to resolve the contradictions between the norms of environmental and mining legislation.

2. Improving methodological framework for assessing the adverse effects of mining waste and compensation of damages to subsoil users from the perspective of the property approach.

3. Introduction of environmental tax.

4. Development of more stringent regulations for storage projects, placement and recycling of technogenic mineral formations.

5. Development of regulatory support of market methods used to promote activities related to mining waste recycling.

\section{CONCLUSIONS}

1. The current trend in the Russian Federation to accumulate mining waste is a consequence of an impact of interconnected negative factors caused by the "conflicts" of the provisions of the mining and environmental legislation in respect of mining waste and the lack of public concepts of waste management.

2. "Non-transparency" of the legislation, which is manifested in inconsistency of the conceptual apparatus of documents regulating the activity in the sphere of mining waste management, as well as - in an uncertain legal status of waste, leads to the violation of legal communications, limiting the powers of their respective owners, hinders the involvement in waste recycling.

3. In foreign practice, the right to private ownership of mining waste is not an obstacle for the implementation of the state policy of resource and energy saving, the involvement of small and medium-sized businesses in the waste management, ensuring the environmental safety, due to the conceptual framework of the current legislation - the protection of the environment.

4. The harmonization of the Russian legislation in the mining waste management shall be carried out on a unified concept of mining waste management, providing its involvement in production, reduction of waste formation and accumulation regardless of the scenario ("conservative" or "liberal") that will finally be selected.

5. Probably, the best option to eliminate existing contradictions in the legislation could be the development of an independent legal act regulating the mining waste management.

\section{REFERENCES}

1. INTOSAI Working Group on Environmental Auditing. Auditing Mining: Guidance for Supreme Audit Institutions., 2010 Retrieved July, 9, 2015, from http://www.environmentalauditing.org/LinkClick.aspx?fileticket=Ffqb/ 3zmeZ8 $=$ \&mid $=568 \&$ tabid $=128$.

2. Ayres, R., \& Simonis, U. (Eds.)., Industrial Metabolism: Restructuring for Sustainable Development. Tokyo \& New York: United Nations University Press. Retrieved July, 9, 2015, from http://archive.unu.edu/unupress/ unupbooks/80841e/80841E00.htm, 1994.

3. EC-Waste Framework Directive. 1991. Retrieved July, 9, 2015, from http:// www.bmub.bund.de/fileadmin/bmu-import/files/ pdfs/allgemein/application/pdf/egabfallrahmenrichtlinie-engl.pdf.

4. The Mines and Minerals Act of Canada. 1991. Manitoba. Retrieved July, 9, 2015, from http:// web2.gov.mb.ca/laws/statutes/ccsm/m162e.php.

5. Scannell, Y. 2012. The Regulation of Mining and Mining Waste in the European Union. Retrieved July, 9, 2015, from http://www.law.wlu.edu/ 
deptimages/journal\%20of\%20energy,\% 20climate,\%20and\%20the\%20environment/3-27-Scannell.pdf.

6. McKinley, À., \& Avenue, H. 2008. Industrial Ecology: A Review with Examples from the Canadian Mining Industry. Retrieved July, 9, 2015, from http://www.cjrs-rcsr.org/archives/311/MACKINLEY.pdf.

7. Bokov, V., Zavertkin, V., \& Lazarev, V. (1994). Wealth in the dumps (problems of disposal of mining and industrial waste in Russia). Center, 8-9.

8. Halperin, A., Kutepov, Y., et al. (2012). Development of technogenic arrays in mining enterprises. Moscow: Mountain Book Publisher.

9. Gorlova, O. (2001). Technogenic mineral deposits. Magnitogorsk: MSTU named after Nosov N.

10. GOST R 53691-2009. National standard of the Russian Federation. Resource saving. Waste management. The certificate for the waste of IIV hazard class. (2009). Retrieved July, 9, 2015, from http://docs.cntd.ru/document/gost-r53691-2009.

11. Kryukov, V., Silkin, V., Tokarev, A., \& Shmat, V. (2011). Mineral resources sector of Russia: the implementation of the benefits and opportunities for development. Mineral Resources of Russia. Economics and Management, 5, 29-35.

12. Makarov, A., \& Talalay, A. (2012). Technogenic mineral deposits. Lithosphere, 1, 172-176.

13. Mormile, S., Salnikov, V., Amosov, L., Khasanova, G., Semyachkov, A., Zobnin, B., \& Burmistrenko, A. (2002). Technogenic deposits of the Middle Urals and assessment of their impact on the environment. Ekaterinburg: NIANature, DPR for the Ural region, JSC "VNIIZARUBEZHGEOLOGIA", Geological company "Devon".

14. Nevskaya, M., \& Ligotskiy, D. (2013). Organizational-economic problems of rational subsoil use and solution of these problems nowadays. Notes of the Mining Institute, NMSU “Mining”, (202), 78-84.

15. Nekrasov, A. (2013). Regulatory and procedural and legal aspects in the geological and economic evaluation and development of technogenic deposits. Moscow. Retrieved July, 9, 2015, from http://www.maxconf.ru/events/past/.

16. The Law of the Republic of Kazakhstan "On Subsoil and Subsoil Use”. (2010, June 24). Retrieved July, 9, 2015, from http:// adilet.zan.kz/rus/docs/Z100000291_.
17. The Law of the Russian Federation "On Subsoil" No. 2395-1. (1992, February 21). Retrieved July, 9, 2015, from http://www.consultant.ru/ popular/nedr/.

18. The Federal Law No. 89-FZ “On Production and Consumption Waste”. (1998, June 24). Consultant Plus, 1992-2015. Retrieved July, 9, 2015, from http://www.consultant.ru/document/ cons_doc_LAW_166431/.

19. Perepelitsyn, V., Rytvin, V., Koroteev, V., Makarov, A., Grigoriev, V., Gilvarg, S., Abyzov, V., Abyzov, A., \& Tabulovich, F. (2013). Technogenic mineral resources of the Urals. Ekaterinburg.

20. Popov, S. (2013). Proposals for improving the state regulation of overburden handling. Materials of the Conference 2013. Problems of mining waste management, Moscow. Retrieved July, 9, 2015, from http://www.maxconf.ru/ events/past/.

21. The Decree of the Government of the Russian Federation as of 07.12.2001 No. 860 (revised on 17.11.2005) "On the federal target program "Ecology and Natural Resources of Russia". (2001). Retrieved July, 9, 2015, from www.consultant.ru.

22. Đongrácz, E., Phillips, P., \& Keiski, R. (2004, June 10). Evolving the Theory of Waste Management Implications to waste minimization. In E. Pongrácz (Ed.), Proc. Waste Minimization and Resources Use Optimization Conference. University of Oulu, Finland. Retrieved July, 9, 2015, from http:// www.researchgate.net/profile/Eva_Pongracz/ citations?sorting $=$ recent $\&$ page $=2$.

23. Đongrácz, E. (2002). Redefining the concepts of waste and waste management. University of Oulu. Retrieved July, 9, 2015, from http://herkules.oulu.fi/ isbn9514268210/isbn9514268210.pdf.

24. Seleznev, S. (2013). Economic and legal aspects of the Russian legislation in the sphere of mining waste management. Materials of the Conference 2013. Problems of mining waste management. Moscow. Retrieved July, 9, 2015, from http:// www.maxconf.ru/events/past/.

25. Trubetskoy, K., Umanets, V., \& Nikitin, M. (1989). Classification of technogenic deposits, the main categories and concepts. Mining Journal, 12, 6-9.

26. Chaynikov, V., \& Goldman, E. (2000). Valuation of investments in the development of technogenic deposits. Moscow: "SubsoilBusiness center”, LLC. 